\begin{tabular}{|lll|}
\hline \multicolumn{3}{|c|}{ TOTOBUANG } \\
\hline Volume 6 & Nomor 2, Desember 2018 & Halaman $169-181$ \\
\hline
\end{tabular}

\title{
TINDAK TUTUR ILOKUSI DALAM CERAMAH USTAD ABDUL SOMAD (Illocutionary Speech Act In Ustadz Abdul Somad Lecture)
}

\author{
Marnetti \\ Balai Bahasa Provinsi Riau \\ Jalan Binawidya, Kompleks Universitas Riau, Panam, Pekanbaru \\ Pos-el: marnettinurel@yahoo.com
}

(Diterima: 17 Oktober 2018; Direvisi: 19 Oktober 2018; Disetujui: 9 November 2018)

\begin{abstract}
This study focuses on illocutionary speech acts used by Ustad Abdul Somad (UAS) in his lecture on September 20, 2018 at Baiturrahmah University, Padang. The objective of this study is to describe the form of illocutionary speech acts used by UAS in his lecture. The research data is the result of UAS lecture transcripts downloaded through www.youtube.com. Data were analyzed by applying some steps, they are 1) reading, understanding, and marking speech acts used by UAS, 2) classifying data based on the types of illocutionary speech acts, 3) interpreting data based on speech forms and other things including the context and speech situation. The results of this study indicate that there are 58 sentences of illocutionary speech acts used by UAS in lecturing. In detail, the 58 illocutionary speech acts are divided into 17 representative illocutionary speech acts, 19 directive illocutionary speech acts, 12 expressive speech acts, 8 commissive speech acts, and 2 declaration speech acts.
\end{abstract}

Keywords: speech acts, illocutionary, lecture.

\section{Abstrak}

Penelitian ini difokuskan pada tindak tutur ilokusi yang digunakan oleh UAS dalam ceramahnya pada 20 September 2018 di Universitas Baiturrahmah, Padang. Penelitian bertujuan mendeskripsikan bentuk tindak tutur ilokusi yang digunakan oleh UAS dalam ceramahnya. Data penelitian ini merupakan hasil transkripsi ceramah UAS yang diunduh melalui www.youtube.com. Data dianalisis dengan langkah-langkah 1) membaca, memahami, dan menandai tindak tutur yang digunakan UAS, 2) mengklasifikasi data berdasarkan jenis tindak tutur ilokusi, 3) menginterpretasikan data berdasarkan bentuk tutur dan hal lain termasuk konteks dan situasi tutur tersebut. Hasil penelitian ini menunjukkan bahwa terdapat 58 kalimat tindak tutur ilokusi yang digunakan oleh UAS dalam berceramah. Secara rinci ke-58 tindak tutur ilokusi tersebut terbagi dalam 17 tindak tutur ilokusi reprentatif, 19 tindak tutur ilokusi direktif, 12 tindak tutur ekspresif, 8 tindak tutur komisif, dan 2 tindak tutur deklarasi.

Kata-Kata Kunci: tindak tutur, ilokusi, ceramah.

\section{PENDAHULUAN}

Komunikasi adalah bagian dari kehidupan manusia (masyarakat). Komunikasi dan masyarakat merupakan dua hal yang tidak akan pernah dapat dipisahkan karena setiap masyarakat pasti melakukan komunikasi dan pengguna komunikasi adalah masusia atau masyarakat. Cangara dalam (Saleh, 2014:43) menyatakan bahwa komunikasi dan masyarakat adalah dua kata kembar yang tidak dapat dipisahkan satu sama lainnya.
Untuk berkomunikasi, diperlukan suatu alat yang dinamakan bahasa. Bahasa digunakan untuk menyampaikan pesan dari seseorang (penutur) kepada orang lain (petutur). Kualitas pesan yang disampaikan sangat ditentukan oleh kemampuan pengirim maupun penerima pesan dalam berbahasa. Manusia dapat mengekspresikan ide, gagasan, dan segala sesuatu yang ada dalam pikirannya dengan menggunakan bahasa.

Dalam pemakaiannya, bahasa memiliki ragam yaitu dalam bentuk tulisan dan bentuk lisan. Bahasa tulis sangat mudah ditemukan 
seperti di koran, majalah, surat, artikel, dan hasil penelitian. Bahasa lisan adalah bahasa yang disampaikan langsung oleh penuturnya seperti yang terdapat dalam ceramah, pidato, berita di televisi atau radio, dan dialog lansung. Ceramah yang merupakan bentuk bahasa lisan sangat sering diadakan oleh pengurus masjid atau majelis-majelis pertemuan.

Salah satu ceramah yang sangat fenomenal saat ini adalah ceramah yang dilakukan oleh Ustad Abdul Somad, biasa disingkat dengan UAS. Bahkan di TV One, UAS secara rutin memberikan ceramah. Tidak hanya melalui media televisi, UAS sangat sering diundang oleh pengurus masjid, pemerintah, dan majelis-majelis dalam berbagai kesempatan. Salah satu keutamaan yang dimiliki oleh UAS adalah ia selalu hadir ketika diundang oleh siapapun dan di manapun. UAS tidak melihat besaran bayaran atau terkenal atau tidaknya pihak yang mengundang. Baginya, menyampaikan ilmu adalah suatu kewajiban yang harus ditunaikannya sebagai orang yang tahu.

UAS lahir di Silo Lama, Asahan Sumatera Utara pada 18 Mei 1977. UAS menamatkan sekolah dasarnya di SD AlWashliyah, Medan tahun 1990. Kemudian UAS melanjutkan pendidikannya ke MTS Mu'alimin Al-Washliyah. Setelah menamatkannya tahun 1993, UAS melanjutkannya ke Pesantren Darularafah Deliserdang Sumatera Utara selama satu tahun. Tahun 1994, UAS hijrah ke Riau dan melanjutkan pendidikannya di Madrasah Aliyah Nurul Falah di Air Molek, Inderagiri Hulu yang diselesaikannya tahun 1996. Di tingkat universitas, UAS mengenyam pendidikan di UIN Suska Riau. Tahun 1998, UAS adalah salah satu dari 100 orang penerima beasiswa dari pemerintah Mesir untuk Pelajar Indonesia. UAS menamatkan pendidikan S-1nya tersebut selama tiga tahun sepuluh bulan. Tahun 2004, UAS terpilih sebagai salah satu penerima beasiswa dari pemerintah Maroko. UAS pun menyelesaikan pendidikan S-2 tersebut hanya dalam waktu satu tahun sebelas bulan.

Dalam kesehariannya, UAS sangat disayangi umat dan pengikutnya. Hal ini bisa dilihat ketika UAS memberikan ceramah, selalu dibanjiri oleh lautan manusia. Bahkan, masyarakat rela mengorbankan biaya yang cukup besar untuk menghadiri pengajian yang disampaikan UAS tersebut. Ketertarikan masyarakat untuk mendengarkan ceramah UAS tentu tidak akan terlepas dari sosok yang didengarnya, baik ilmu, cara penyampaian, maupun materi yang disampaikannya. Secara keilmuan, konsentrasi UAS adalah pada tafsir hadis. Dari cara membahas segala sesuatunya, UAS selalu melandasinya dengan dalil-dalil yang sangat kuat dan meyakinkan. Di samping itu, cara penyampaian UAS juga sangat lugas, tegas, dan UAS juga dikenal sebagai ustad yang lucu, kocak, dengan kekhasan logat Riaunya yang bercampur dengan logat Medan. Begitu juga dengan materi-materi yang disampaikan, UAS selalu membahas hal-hal yang memang dialami dan juga sering hal-hal yang menjadi kegalauan masyarakat dalam menjalankan ibadah. Mungkin, hal-hal tersebutlah yang menyebabkan masyarakat sangat menyukai UAS hingga hari ini.

Penelitian ini membahas tindak tutur ilokusi yang digunakan UAS dalam menyampaikan ceramah. Kajian tentang tindak tutur sebenarnya sudah pernah dilakukan oleh Elmita, W., Ermanto, Ratna (2017) yang berjudul "Tindak Tutur Direktif Guru dalam Proses Belajar Mengajar di TK Nusa Indah Banuaran Padang. Hasil penelitian tersebut menunjukkan bahwa tindak tutur direktif guru dalam proses belajar mengajar di TK Nusa Indah Banuaran Kecamatan Lubuk Begalung Padang ada lima bentuk, yaitu tindak tutur direktif menyuruh, tindak tutur direktif memohon, tindak tutur direktif menyarankan, tindak tutur direktif menasehati dan tindak tutur direktif 
menantang. Strategi bertutur yang digunakan dalam proses belajar mengajar ada dua, yaitu strategi bertutur terus terang tanpa basa-basi dan strategi dan strategi bertutur terus terang dengan basa-basi kesantunan positif.

Penelitian lain yang terkait dengan penelitian ini dilakukan oleh (Ellini, M., Juita, N., dan Hamidin (2014) yang berjudul "Tindak Tutur Ilokusi Ustad Yusuf Mansur dalam Acara Wisata Hati di Stasiun Televisi ANTV". Hasil penelitian tersebut menunjukkan bahwa terdapat 233 tuturan. Di antaranya tindak tutur representatif, tindak tutur direktif, tindak tutur ekspresif dan tindak tutur deklarasi. Strategi bertutur yang digunakan dalam acara Wisata Hati di stasiun televisi ANTV, yaitu strategi bertutur terus terang tanpa basa-basi, strategi bertutur dengan kesantunan negatif. Konteks situasi tutur dalam tindak tutur ilokusi Ustaz Yusuf Mansur dalam situasi tutur topik sensitif suasana santai, cenderung digunakan strategi bertutur terus-terang dengan basa-basi kesantunan positif; dalam situasi tutur topik sensitif suasana formal, cenderung digunakan strategi bertutur terus-terang dengan basa-basi kesantunan negatif; dalam situasi tutur topik tindak sensitif suasana santai, cenderung digunakan strategi bertutur terus-terang tanpa basa-basi: dalam situasi tutur topik tidak sensitif suasana formal, cenderung digunakan strategi bertutur terusterang tanpa basa-basi.

Penelitian terkait yang ketiga dilakukan oleh Wijayanti (2014) yang berjudul "Tindak Tutur Tokoh Dalam Novel Bekisar Merah" Karya Ahmad Tohari. Penelitian ini menunjukkan bahwa tindak tutur merupakan komponen utama dalam sebuah komunikasi antara penutur dan mitra tuturnya. Komunikasi yang terjadi dalam percakapan antar tokoh dalam novel Bekisar Merah mempunyai bentuk yang tidak sama yang oleh Austin dikelompokkan menjadi lokusi, ilokusi, perlokusi. Setiap tuturan mempunyai keterkaitan antara tindak lokusi, tindak ilokusi dan tindak perlokusi, sehingga setiap kalimat memiliki kemungkinan menjadi sebuah tindak lokusi, ilokusi maupun tindak perlokusi.

Setyanto (2015) juga melakukan penelitian tentang tindak tutur yang berjudul "Tindak Tutur Dialog Film 5 CM Karya Rizal Mantovani (Sebuah Tinjauan Pragmatik). Hasil penelitian ini menunjukkan terdapat 45 tindak tutur ilokusi Asertif, 15 Tindak Tutur ilokusi Direktif, 13 Tindak Tutur ilokusi Ekspresif, 5 Tindak Tutur ilokusi Komisif dan 2 Tindak Tutur ilokusi Deklaratif. Selain itu, terdapat pula 16 maksud tuturan ilokusi yaitu menyatakan, mengusulkan, mengelih, dan melaporkan.

Penelitian ini berbeda dengan penelitian terdahulu yang telah dilakukan sebelumnya oleh peneliti lain. Perbedaan tersebut terutama dilihat dari objek yang diteliti. Secara umum, kajian-kajian terdahulu tentang ilokusi yang dijadikan objek penelitiannya misalnya, film, novel, dan karya sastra lainnya. Namun, objek penelitian ini adalah ceramah agama yang disampaikan UAS di Universitas Baiturrahmah, Padang pada 20 September 2018 yang lalu. Selain itu, UAS merupakan sosok yang fenomena saat ini dengan gaya bahasanya dalam menyampaikan ceramah agama.

Berdasarkan uraian pada latar belakang tersebut, peneltian ini difokuskan pada tindak tutur ilokusi dalam cerama UAS. Dengan demikian, penelitian ini bertujuan untuk mendeskripsikan bentuk tindak tutur ilokusi yang digunakan oleh UAS dalam ceramahnya. Penelitian ini diharapkan dapat memberikan pemahaman yang baik terhadap pendengar ceramah UAS. Di samping itu, penelitian ini juga bermanfaat untuk pengembangan khazanah keilmuan terutama terkait dengan tindak tutur sebagai bagian dari pragmatik. Bagi peneliti lain, penelitian ini tentu diharapkan dapat menjadi bahan rujukan untuk melaksanakan penelitian sejenis. 


\section{LANDASAN TEORI}

Dalam pragmatik, bahasa lisan diwujudkan dalam bentuk tuturan dan proses ini dikenal dengan istilah tindak tutur. Menurut Elmita, W., Ermanto, dan Ratna (2017:139) mengatakan bahwa tindak tutur adalah sesuatu yang dikatakan sambil bertindak sesuai dengan apa yang dikatakan dan adanya reaksi yang diharapkan dari kata-kata tersebut. Tindak tutur dan peristiwa tutur merupakan dua gejala yang terdapat dalam proses komunikasi dalam menyampaikan atau menyebutkan suatu maksud oleh penutur.

Kristanti (2014:11) juga menyatakan pendapatnya bahwa tindak tutur merupakan perwujudan dari fungsi bahasa. Di balik suatu tuturan terdapat fungsi bahasa yang tercermin dalam maksud dari tuturan tersebut. Pendapat lain menjelaskan tentang tindak tutur bahwa sebagai gejala individual, tindak tutur bersifat psikologis dan keberlangsungannya ditentukan oleh kemampuan bahasa si penutur dalam menghadapi situasi tertentu (Chaer, S.A., dan Agustina, 1995:65). Dari pendapat tersebut, disimpulkan bahwa tindak tutur adalah tuturan yang disampaikan oleh penutur yang di dalamnya mengandung fungsi bahasa agar adanya reaksi yang diharapkan dari pendengar tuturan tersebut.

Searle dalam Kusumaningsih (2016:10) menyatakan bahwa secara pragmatis tindak tutur terdiri dari tiga jenis bentuk tindakan bahasa yang dapat diwujudkan seseorang dalam bertutur, yaitu tindak lokusi, tindak ilokusi, dan tindak perlokusi. Tindak tutur ilokusi (The Act of doing Something) adalah sebuah tuturan selain untuk mengatakan atau menginformasikan sesuatu, juga dapat dipergunakan untuk melakukan sesuatu sejauh situasi tuturnya dipertimbangkan secara seksama Wijana dalam (Rahma, 2014:14). Pendapat Austin yang dikutip oleh Hibridani, I. (2010:21) berpendapat ilokusi atau tindak ilokusi adalah tindak melakukan sesuatu. Tindak ilokusi merupakan suatu tuturan yang mengandung maksud dan fungsi atau daya tuturan.

Ilokusi adalah susuatu yang ingin dicapai oleh penuturnya pada waktu menuturkan sesuatu dan dapat merupakan tindakan menyatakan, berjanji, minta maaf, mengancam, meramalkan, memerintah, meminta, dan lain sebagainya (Nadar, 2009:14). Selanjutnya, Searle dalam (Ellini, M., Juita, N., dan Hamidin (2014) membagi tindak tutur menjadi lima jenis, yaitu tindak tutur representatif, tindak tutur direktif, tindak tutur ekspresif, tindak tutur komisif, dan tindak tutur deklarasi. Leech (1993:316) ilokusi berarti melakukan tindakan dalam mengatakan sesuatu. Tindak ilokusi itu berkaitan dengan siapa bertutur, kepada siapa, kapan dan di mana tindak tutur dilakukan. Pada tindak tutur ilokusi, perlu disertakan konteks tuturan dalam situasi tutur.

\section{METODE PENELITIAN}

Jenis penelitian ini adalah kualitatif dengan menggunakan metode deskriptif. Pemilihan jenis dan metode penelitian ini didasarkan pada data dan teori yang digunakan. Data dalam penelitian ini adalah video ceramah UAS yang diunduh dari www.youtube.com. Ceramah ini disampaikannya di Padang, pada tanggal 20 September 2018 yang lalu. Setelah diunduh, video ceramah tersebut dibuat transkripsinya sehingga menjadi sebuah teks untuk memudahkan penganalisisan. Analisis data dilakukan dengan merujuk teori yang telah dibahas pada bagian sebelumnya, yaitu teori tentang tindak tutur ilokusi. Setelah dibuat transkripsinya, teks tersebut kemudian dibaca dan ditandai yang merupakan bagian dari tindak tutur ilokusi yang digunakan UAS dalam menyampaikan ceramahnya. Setelah diperoleh data yang merupakan tuturan ilokusi UAS, kemudian data tersebut diklasifikasikan berdasarkan jenis tindak tutur ilokusi, yaitu tindak tutur representatif, tindak tutur direktif, tindak tutur ekspresif, tindak tutur komisif, dan tindak tutur 
deklarasi. Setelah diklasifikasikan, kemudian data diinterpretasi berdasarkan bentuk tutur dan hal-hal lain termasuk konteks situasi tutur tersebut.

\section{PEMBAHASAN}

Berdasarkan analisis yang dilakukan, ditemukan 62 tindak tutur ilokusi yang digunakan oleh UAS dalam menyampaikan cermahnya di Padang pada 20 September 2018. Berikut adalah uraiannya.

\section{A. Tindak Tutur Representatif}

Tindak tutur representatif berfungsi untuk menyatakan sesuatu agar dapat dinilai benar atau tidaknya. Misalnya menyatakan, menunjukkan, dan menyebutkan (Sherry HQ dan Agustina, 2012:63).

\section{a. Menyatakan}

Berdasarkan temuan hasil penelitian tindak tutur representatif 'menyatakan" terdapat pada kalimat berikut ini.

1) "Ternyata setelah sampai, diberi tahu Ibu bahwa hari ini tepat, tidak ada direncanakan, sudah begitu takdir Allah, bertepatan dengan Tuan H. Amran berusia 89 tahun."

2) "Ternyata saya tengok kiri kanan, tak ada lilin. Rupanya begitu cara mensyukuri nikmat Allah dengan bersama-sama berdoa di dalam masjid."

3) Maka kedatangan ini, tak lain tak bukan, menyambung silaturahmi.'

4) "Ini pelajaran penting."

5) "Siapa pun bisa bersedekah."

6) "Lebih baik pakai baju setan tapi isinya malaikat, dari pada pakai bajunya malaikat isinya setan."

7) "Tertidur sampai subuh, tidak jadi salat tahajud, dapat pahala tahajud."

8) "Orang yang mati syahid lansung masuk surga kecuali hutang."
9) Berlomba-lomba orang ingin mendapatkan fasilitas yang baik, dunia dapat akhirat melayang."

Pada tindak tutur representatif terdapat sembilan kalimat "menyatakan" yang digunakan oleh UAS dalam ceramahnya. Data 1 terjadi ketika UAS menceritakan bahwa baru sampai di Padang, ia berkomunikasi dengan istri H. Amran yang mengundangnya pada pengajian tersebut. UAS menyatakan bahwa pengajian ini bertepatan dengan hari ulang tahun ke-89 $\mathrm{H}$. Amran hanya kebetulan belaka dan tidak ada direncanakan. Data 2 disampaikan UAS ketika baru memulai memberikan ceramah. UAS ingin menyampaikan kepada jemaah bahwa beginilah cara mensyukuri nikmat Allah saat diberikan umur yang panjang, yaitu dengan berdoa bersama-sama dalam masjid. Hal ini dinyatakan oleh UAS karena banyak zaman sekarang yang keliru dalam mensyukuri nikmat Allah tersebut, misalnya dengan acara tiup lilin, nyanyi-nyanyi di karaoke, dan sebagainya.

Pada data 3, UAS memberikan pernyataan bahwa kedatangannya ke Padang seolah-olah bukanlah seperti kedatangan yang biasa dilakukannya. Kedatangannya ke Padang dianggapnya seperti pulang ke kampung sendiri. Hal ini dilakukannya agar jemaah merasa dekat dengan UAS sehingga terjadi komunikasi yang baik selama pengajian berlansung. Data 4 UAS menyatakan bahwa 'ini pelajaran penting'." Kata 'ini' yang dimaksudkan oleh UAS dalam pernyataan tersebut merujuk pada kegiatan atau cara H. Amran dan keluarga memperingati hari ulang tahunnya. UAS sengaja memberikan penekanan intonasi terhadap kalimat tersebut karena ia ingin menekankan bahwa cara mensyukuri nikmat Allah harus sesuai dengan ajaran agama.

Pada data 5, UAS menyatakan bahwa siapa pun bisa bersedekah. Untuk mendukung pernyataan ini UAS memberikan contoh seorang dokter yang bisa membantu proses kitanan seseorang. Pernyataan ini disampaikan oleh UAS untuk 
mempertegas anjuran sebelumnya bahwa kita harus memahami dakwah itu juga bagian dari ceramah. Data 6 merupakan sebuah pernyataan UAS bahwa yang paling terpenting menjadi manusia adalah isi dari hati kita, tetapi bukan apa yang kita pakai atau tampilkan dan yang terlihat oleh orang lain. Apapun profesi kita yang palin penting adalah kita harus berbuat baik terhadap orang lain.

Data 7 merupakan pernyataan tentang pahala yang diberikan Allah terhadap hamba-Nya yang sudah berniat baik. UAS mencontohkan seorang yang sudah berniat untuk salat tahajud. Seseorang yang sudah berniat untuk melaksanakan salat tahajud, meskipun dia tertidur dan tidak jadi salat tahajud yang bersangkutan tetap mendapatkan pahala karena sudah berniat baik. Data 8 adalah pernyataan UAS tentang seseorang yang mati syahid. Disebutkannya bahwa seseorang yang mati syahid sudah pasti masuk surga. Namun, pernyataan ini disampaikannya untuk menegaskan bahwa setiap hutang harus dibayar, walaupun dianggap mati syahid, hutang tetap harus dibayar. Terakhir, data 9 merupakan pernyataan tentang kondisi masyarakat yang banyak lebih mementingkan dunia dari pada akhirat. Misalnya, seorang dosen yang membuat jadwal kuliah pada waktu jam salat, dosen tersebut tidak mengizinkan mahasiswanya yang meminta izin untuk melaksanakan salat.

Kesembilan tindak tutur representatif 'menyatakan' tersebut memiliki kesamaan. Kesamaan tersebut tertutama terkait dengan ketegasan UAS dalam menyampaikannya pernyataannya. Artinya, dalam persoalan akidah tidak ada istilah tawar-menawar karena itu memang sudah ketentuan dari Allah. Bukti lain ketegasan tersebut bisa diketahui dari dalil-dalil yang digunakan UAS terkait dengan pernyataannya.

\section{b. Menunjukkan}

Berikut adalah data tindak tutur ilokusi representatif 'menunjukkan.'
10) "Coba tengok, baju kaus, celana, jeans, kan tidak ustad."

11) "Ada yang ceramah lewat kata, ada yang ceramah lewat gambar, ada yang ceramah lewat video."

12) "Karena itu yang akan menolong di hadapan Allah."

13) "Kepala boleh panas, tapi hati tetap dingin."

14) "Jangan kau pandang hartanya, yang harus dilihat taat beragama, sopan, baik akhlaknya."

Pada tindak tutur representatif 'menunjukkan' terdapat lima kalimat UAS yang merupakan tuturan ilokusi. Data 10 adalah pernyataan UAS yang menunjukkan bahwa untuk berbuat suatu kebaikan tidak hasur menjadi ustad. UAS mencontohkan yang sedang terjadi di hadapannya tentang seorang kamerawan yang merekam acara tersebut. Jika hasil rekaman tersebut disiarkan kepada orang banyak, maka kamerawan mendapatkan pahala dari pekerjaannya itu karena dia telah menyebarkan ceramah agama kepada orang banyak. Data 11 menyebutkan bahwa cara berceramah dalam artian yang lebih luas sebenarnya tidak hanya seperti yang ia lakukan saat itu. Untuk menyampaikan sesuatu yang memiliki pesan-pesan yang baik, orang tersebut bisa saja mengemasnya dalam bentuk ceramah, gambar, video, dan sebagainya.

Pada data 12 UAS ingin menunjukkan bahwa seorang hamba harus lebih mendahulukan kewajibannya dari pada urusan-urusan dunia. UAS menegaskannya petunjuk tersebut bahwa ketika mendengar suara azan, semua aktivitas harus dihentikan dan harus bergegas melaksanakan ibadah salat karena hal itulah yang akan menolong kita di akhirat nanti. Pada data 13 UAS menunjukkan kepada jemaah bahwa dalam kehidupan berumah tangga harus selalu sabar dan ikhlas menghadapi cobaan dan dalam berkomunikasi. UAS menjelaskan dalam diri manusia ada hati yang akan menentukan sikapnya, jika hati itu baik 
maka sikap kita akan baik. Sebaliknya, jika hati itu tidak baik maka sikap kita juga tidak akan baik. Melalui data 14, UAS ingin memberikan petunjuk kepada orang tua yang memilih jodoh untuk anaknya. Zaman sekarang, banyak orang tua yang memprioritaskan calon menantunya kaya dan banyak harta. UAS memberi petunjuk bahwa yang lebih penting itu adalah agama, akhlak, dan sopan-santunnya.

\section{c. Menyebutkan}

Berikut adalah data tindak tutur ilokusi representatif 'menyebutkan.'

15) "Baiturrahmah berarti rumah yang diisi dengan kasih sayang."

16) "Sengaja saya jelaskan, jangan ada dusta diantara kita."

17) "Yang kau makan busuk, yang kau pakai lapuk, yang kau sedekahkan, wakafkan ...."

Pada data 15 UAS menyebutkan kepada jemaah arti dari nama masjid tempat tausiah dilaksanakan, yaitu Baiturrahmah yang rumah yang diisi dengan kasih sayang. Dalam kesempatan itu, UAS sengaja memberi petunjuk perlunya kasih sayang dalam kehidupan sehari-hari. Data 16 disampaikan oleh UAS sambil bercanda. Namun, di situ terdapat makna yang sangat dalam. Konteks pembicaraan saat itu adalah UAS sebelumnya memberikan anjuran untuk selalu melaksanakan salat berjemaah. Akan tetapi, UAS khawatir jemaah protes karena ia tidak selalu melaksanakan salat berjemaah. Dalam hal tersebut, UAS punya alasan penting tidak melaksanakan salat berjemaah pada kondisi tertentu. Pada data 17 UAS menyebutkan bahwa semua yang kita miliki di dunia ini akan habis begitu saja, yang hanya akan kita bawa ke akhirat hanyalah perbuatan atau amal baik seperti sedekah, salat, dan sebagainya.

\section{B. Tindak Tutur Direktif}

Tindak tutur direktif adalah tindak tutur yang bertujuan menghasilkan efek berupa tindakan yang dilakukan oleh pendengar misalnya memesan, memerintah, memohon, menuntut, menasehatkan, meminta, melarang, membolehkan, menanyakan, dan mengancam (Sherry HQ dan Agustina, 2012:64). Namun, tidak semua bagian tersebut dianalisis dalam penelitian ini.

\section{a. Menyuruh}

Berikut adalah data tindak tutur ilokusi direktif 'menyuruh.'

18) "selesai acara pengajian, pulang dengan tenang, jangan berdesakdesakan, ambil sampah, tutup botol. Tunjukkan bahwa Islam agama indah, agama yang santun."

19) "Kalau sanggup buat di masjid dengan tablig akbar, kalau tak sanggup nasi bungkus ke panti asuhan."

20) "oleh sebab itu pahami dakwah dengan baik."

21) "Tak bisa bangun masjid, makmurkan masjid, salat berjemaah

22) "Banyak salah dan khilaf, kalau punya dosa ngakunya sama Allah, jangan di facebook."

23) "Anak pertama lahir harus diazankan di telinga kanannya, supaya masuk kalimat tauhid ke otaknya."

Pada data 18 UAS menyuruh jemaah untuk membiasakan hidup bersih seperti yang diajarkan Islam. Salah satunya adalah sambil pulang pengajian tersebut, jemaah disuruh untuk memungut sampah. UAS menyuruh jemaah untuk menunjukkan bahwa Islam adalah agama yang bersih dan santun. Data 19 adalah suruhan UAS terhadap jemaah untuk selalu berbuat baik sesuai dengan kemampuan masing-masing. Hal itu terkait dengan cara mensyukuri usia yang diberikan Allah yang benar menurut ajaran agama. Hal ini bisa dilaksanakan dengan melaksanakan tablig akbar seperti yang dilakukan oleh $\mathrm{H}$. Amran atau dengan membelikan anak panti asuhan nasi bungkus. 
Pada data 20 UAS menyuruh jemaah untuk memahami dakwah dengan baik. Dakwah bisa dilakukan dengan banyak hal, tidak harus dengan melakukan ceramah agama seperti yang dilakukannya saat itu. Dakwah bisa dilakukan oleh siapa saja dan dengan berbagai cara. Bisa dilakukan oleh dokter terhadap pasiennya, bisa dilakukan oleh polisi terhadap masyarakat, dan lainlain. Data 21 UAS menyuruh jemaah untuk berbuat baik sesuai dengan kemampuan kita masing-masing. Dalam membangun masjid, jika memang tidak ada kemampuan untuk membantu pembangunan secara fisik, dengan selalu ikut salat berjemaah, artinya kita sudah ikut membangun masjid di lingkungan kita.

Pada data 22 UAS mengingatkan kepada jemaah bahwa dalam kehidupan sehari-hari banyak salah dan khilaf yang telah kita perbuat. Untuk itu, jemaah dianjurkan untuk mengadu kepada Allah, tidak membuat status di media sosial seperti yang dilakukan banyak orang sekarang ini. Selajutnya, data 23 mengingatkan jemaah untuk memberikan pendidikan yang baik menurut ajaran agama kepada anak mulai dari anak itu lahir. Jika lahir anak laki-laki maka harus diazankan di telinga kanan anak tersebut agar otaknya diisi dengan kalimatkalimat tauhid.

\section{b. Memohon}

Berikut adalah data tindak tutur ilokusi direktif 'memohon.'

24) "Insya Allah kita semua dimuliakan Allah."

25) "Mudah-mudahan diberikan Allah keberkahan umur, Aamiin."

26) "Mudah-mudahan rahmat senantiasa turun ke sini, Insya Allah."

27) "Ya Allah, catatkanlah Aku dan Tuan H. Amran beserta keluarganya, mudah-mudahan kami berkasih sayang karena Allah."
28) "Mudah-mudahan anak cucu-cicit kita kaya-kaya."

29) "Mudah-mudahan yang belum nikah ditemukan jodoh yang baikbaik."

30) "Mudah-mudahan yang dulunya pacaran, sekarang hijrah."

Tuturan 24 adalah permohonan yang disampaikan UAS agar seluruh jemaah yang hadir dimuliakan Allah. Permohonan ini disampaikan UAS untuk menyapa seluruh jemaah yang hadir dalam majeleis tersebut. Data 25 UAS memohn kepada Allah agar yang mengundangnya dalam pertemuan tersebut diberikan Allah keberkahan umur. Sebelumnya UAS tidak tahu bahwa yang mengundangnya pengajian saat itu kebetulan sedang berulang tahun. Jadi UAS mengucapkan selamat dengan memohon kepada Allah agar umur yang dimilikinya berkah. Pada data 26 UAS bermohon agar rahmat selalu diturunkan Allah kepada jemaah yang hadir pada pengajian itu. Sebelumnya UAS memuji cara bersyukur yang dilaksanakan oleh $\mathrm{H}$. Amran, yaitu dengan cara melakasankan tablig akbar dan tidak seperti yang dilakukan kebanyakan orang dalam mensyukuri nikmat umur yang diberikan.

Pada data 27 UAS kembali berdoa dan bermohon agar dirinya dan H. Amran dan keluarganya diberikan rasa berkasih sayang karena Allah. Hal ini disampaikan UAS karena dia telah diberi kesempatan untuk memberikan pengajian. Data 28 merupakan harapan UAS agar dia dan jemaah yang hadir pada majelis tersebut diberikan keturunan yang kaya-kaya. Tujuannya adalah agar keturunan mereka nanti bisa berbuat kebaikan dengan harta yang dimilikinya, salah satunya adalah dengan membangun masjid. Data 29 UAS mendoakan agar Allah memberikan jodoh bagi yang belum mendapatkan jodoh. Hal ini disampaikan untuk mempertegas bahwa perlunya memiliki keturunan yang baik, tentu harus memiliki pasangan hidup yang baik pula. Pada data 30 UAS mengajak 
seluruh jemaah untuk hijrah kepada jalan Allah. Khusus kepada yang masih mudamuda, UAS berpesan bagi mereka yang dulunya suka berpacaran, agar hijrah untuk menjalin hubungan sesuai dengan ajaran Islam.

\section{c. Menyarankan}

Berikut adalah data tindak tutur ilokusi direktif 'menyarankan.'

31) "Buatlah operasi bibir sumbing gratis. Buatlah operasi khitanan massal gratis."

32) "Mari puasa sunat, ini bulan mulia, bulan Arab."

33) "Baca saja doa ketika Nabi Ibrahim dibakar."

34) "Yang punya harta, bangun masjid."

35) "Kalau tidak sanggup bangun masjid, setidaknya salat di masjid."

36) "Mandi taubat dulu kemudian salat taubat."

Pada data 31 UAS menyarankan kepada jemaah bahwa berdakwa bisa dilakukan dengan banyak cara dan oleh siapa saja. Seorang dokter bisa berdakwah dengan membuat operasi bibir sumbing dan kitanan secara gratis. Jadi, UAS berpesan apa pun profesi yang digeluti, dengan keahlian yang dimiliki tersebut kita bisa berdakwah. Data 32 merupakan saran yang disampaikan oleh UAS kepada jemaah untuk melaksanakan puasa sunnah. Apalagi, waktu pengajian tersebut berlangsung, bertepatan dengan bulan yang dimuliakan Allah, yaitu Muharram. Pada data 33 UAS memberikan saran kepada jemaah yang hadir untuk membaca doa nabi Ibrahim ketika dibakar. Hal ini sesuai dengan kondisi suhu di dalam masjid waktu itu. UAS mencoba menelaah terkait keadaan suhu di dalam masjid yang besar dan mungkin terasa panas. UAS mengingatkan bahwa tidak ada satu hal pun yang bisa menghalangi jika kita ingin berbuat baik walaupun suhunya panas.

Pada data 34 UAS menyarankan kepada jemaah yang mungkin diberikan rezeki banyak oleh Allah untuk membangun masjid. UAS menjelaskan bahwa siapa yang berbuat satu kebaiakan, Allah akan membalas dengan sepuluh kali kebaikan. UAS menekankan bahwa rezeki yang diberikan oleh Allah hanyalah titipan, semuanya milik Allah, dan harus digunakan kembali di jalan Allah. Masih terkait dengan data 34, data 35 juga menyarankan kepada jemaah untuk selalu berbuat kebaikan sesuai dengan kemampuan masing-masing. Dengan melaksanakan salat berjemaah di masjid, artinya kita sudah ikut untuk membangun masjid, tetapi tidak dalam bentuk fisik. Pada data 36, UAS memberikan saran kepada jemaah jika ingin bertobat, sebaiknya mandi tobat terlebih dahulu.

\section{Tindak Tutur Ekspresif}

Tindak tutur ekspresif adalah tindak ilokusi yang mempunyai fungsi untuk mengekspresikan, mengungkapkan, atau memberitahukan sikap psikologis sang pembicara menjadi suatu pernyataan keadaan yang diperkirakan oleh ilokusi, seperti mengucapkan terima kasih, meminta maaf, mengharapkan, merasa ikut simpati, penerimaan dan sebagainya (Sherry HQ dan Agustina, 2012:64).

\section{a. Memuji}

Berikut adalah data tindak tutur ilokusi ekspresif 'memuji.'

37) "Saya datang ke Sumatera Barat tidak dianggap orang jauh, tapi saya dianggap anak kemenakan yang pulang ke kampung halaman."

38) "Mereka tidak ceramah, mereka tidak tabliq Akbar, cukup dengan perbuatan, karena perbuatan lebih menyentuh hati dan perasaan."

39) "Sampai umur 80 tahun masih salat berjemaah di masjid."

40) "Sudahlah membangun masjid, pergi salat ke masjid, dua-duanya dapat." 
Pada data 37, UAS memberikan pujian kepada H. Amran dan semua jemaah karena telah mengundang dan menganggapnya sebagai bagian dari keluarga mereka. Data 38 UAS memberikan pujian terhadap yang mengundangnya pada tablig akbar tersebut karena UAS menganggap langkah yang diambil oleh $\mathrm{H}$. Amran dan keluarga sangat tepat. Pada data 39, kembali UAS memberikan pujian kepada jemaah yang sudah terbilang lansia, khususnya kepada $\mathrm{H}$. Amran. Walaupun sudah tua tetap semangat menjalankan ibadah dan salat berjemaah di masjid. Sebenarnya dalam hal ini UAS tidak mengetahui secara baik apakah H. Amran benar-benar rajin salat berjemaah di masjd atau tidak. Namun, UAS tetap memberikan pujian. Data 40 berupa pujian UAS terhadap jemaah yang sudah ikhlas membantu dalam pembangunan masjid itu, apalagi jemaah yang membantu dan ikut salat berjemaah. Dalam hal ini sebenarnya UAS tidak mengetahui siapa yang menyumbang untuk pembangunan dan yang biasanya melaksanakan salat berjemaah di masjid tersebut.

\section{b. Berterima kasih}

Berikut adalah data tindak tutur ilokusi ekspresif 'berterima kasih.'

41) "Andailah tak dibuat acara hari ini, saya tak jumpa dengan Tuan $\mathrm{H}$. Amran, saya tak jumpa dengan Pak Rektor, dengan bapak-bapak dekan, dengan TNI dan Polri."

Pada data 41 di atas, UAS mengcapkan terima kasih kepada H. Amran yang telah mengundangnya dalam pengajian tersebut. Melalui undangan tersebut, UAS dapat bersilaturrahmi dengan berbagai latar belakang jemaah yang hadir saat itu.

\section{c. Mengkritik}

Berikut adalah data tindak tutur ilokusi ekspresif 'mengkritik.'

42) "Yang saya khawatirkan tadi, saya diminta meniup lilin bersama."
43) "Sudahlah tak bisa bangun masjid, tak ngasih semen, senyum tak bisa."

44) "Laki-laki yang saleh salat di masjid, yang salat di rumah lakilaki saleha."

45) "Akhirnya dimakan pil anjing gila, baru agak tenang."

46) "Rupanya orang kalau rezekinya sudah lancar tak ke masjid lagi."

47) Sombong, angkuh luar biasa."

48) "Kalau sekarang, ditanya bisa nyetir tidak? Punya mobil tidak?

Data 42 merupakan kritikan yang disampaikan UAS terhadap jemaah dan masyarakat secara umum yang masih melaksanakan ulang tahun dengan cara yang tidak sesuai dengan ajaran agama. data 43 merupakan tuturan yang bernada kritis terhadap orang yang tidak mau menyumbang pembangunan masjid, bahkan untuk senyum pun susah. UAS sebenarnya bermaksud mengimbau masyarakat untuk berlomba-lomba dalam berbuat kebaikan, salah satunya dengan bersedekah membantu pembangunan masjid. Data 44 merupakan kritikan UAS terhadap laki-laki yang tidak salat berjemaah di masjid. Dalam ajaran Islam laki-laki sebaiknya salat berjemaah di masjid, dan jika tidak salat di masjid dianggap saleha. Hal ini berarti laki-laki tersebut disamakannya dengan perempuan.

Data 45 merupakan kritikan UAS terhadap masyarakat yang suka mabukmabukan ketika merayakan ulang tahun. Bahkan, UAS mengkritik dengan keras masyarakat yang menggunakan obat-obat terlarang ketika merayakan uang tahun, ia mengistilahkannya dengan sebutan pil anjing gila. Pada data 46 UAS mengkritik bagi remaja-remaja yang tidak lagi mengaji ke masjid. Hal ini memang terjadi di tengahtengah masyarakat, bahwa banyak anak yang hanya mau mengaji ke masjid menjelang menginjak masa remaja. Setelah mereka bisa mengaji, mereka tidak mau ke masjid lagi.

Data 47 merupakan kritikan keras UAS terhadap orang yang sombong dan angkuh. 
Orang sombong dan angkuh yang dimaksudkan UAS di sini adalah orang yang tidak mau menyumbang untuk pembangunan masjid dan tidak salat berjemaah ke masjid. Data 48 merupakan kritikan terhadap kebiasaan orang tua zaman sekarang ketika mencari jodoh untuk anaknya yang ditanya adalah hartanya. UAS menyarankan agar yang dilihat bukan hartanya, tetapi akhlak dan keimanannya.

\section{Tindak Tutur Komisif}

Tindak tutur komisif berfungsi untuk menyatakan sesuatu yang menunjukkan bahwa penutur sedikit banyak terkait pada suatu tindakan pada masa depan. Misalnya, berjanji, bersumpah, dan mengancam (Sherry HQ dan Agustina, 2012:64).

\section{a. Mengancam}

Berikut adalah data tindak tutur ilokusi komisif 'mengancam.'

49) "Akan menjadi anak konsumtif."

50) "Nanti kalau kamu macam-macam akan ditinggalkan di sini."

51) "Itu (pil anjing gila) yang dimakan orang sekarang."

52) "Berkasih sayang karena kuasa tak lama lagi KPK akan tiba."

53) "Yang sombong tak mau di belakang imam (salat berjemaah), nanti diletakkan di depan imam (disalatkan)."

Ancaman yang disampaikan oleh UAS dalam pengajian ini disampaikan dengan baik dan lembut. UAS sebenarnya ingin memberi peringatan kepada jemaah tentang berbagai hal. Pada data 49 UAS mengancam bagi orang tua yang membiasakan anaknya menerima hadiah ulang tahun secara rutin. Dengan kebiasaan seperti itu, anak akan menjadi konsumtif dan menuntut hadiah dari orang tuanya setiap ulang tahun. Hal ini merupakan kebiasaan yang tidak mendidik, oleh sebab itu UAS memberikan ancaman kepada jemaah agar tidak membiasakannya lagi. Data 50 sebenarnya berupa candaan UAS, tetapi candaan tersebut bernada ancaman kepada anak. Hal ini bertujuan membiasakan anak merayakan ulang tahun sesuai syariat Islam.

Data 51 berupa ancaman yang ditujukan kepada pemakai narkoba dan sejenisnya. UAS menyebutkan bahwa pil yang biasanya dikonsumsi para pemakai narkoba tersebut adalah pil yang digunakan untuk menenangkan anjing gila. Data 52 juga berupa ancaman, tetapi ancaman ini ditujukan kepada orang yang biasanya ambisi terhadap jabatan atau kekuasaan. Saat ini, banyak pejabat-pejabat yang terjerat kasus korupsi. Sehubungan dengan itu, sambil bercanda UAS memberikan ancaman kepada orang yang ambisi terhadap kekuasaan atau yang menyalahgunakan kekuasaan akan segera berurusan dengan KPK. Data 53 adalah ancaman yang sengaja ditujukan orang atau jemaah yang malas untuk mengerjakan salat berjemaah di masjid. UAS mengancam sambil bercanda, yaitu bagi yang tidak mau salat di belakang imam (salat berjemaah), nanti akan diletakkan di depan imam (sudah menjadi jenazah).

\section{b. Bersumpah/berjanji}

Berikut adalah data tindak tutur ilokusi Komisif 'bersumpah/berjanji.'

54) "kalau tidak bisa saya jawab, saya bawa pulang ke Pekanbaru."

55) "Supaya aku tetap bisa berkawan denganmu."

56) "Kita semua bersaudara, orang Bugis, orang Jawa, orang Minang, orang Melayu."

Data 54 merupakan janji yang disampaikan UAS. Janji tersebut adalah jika ia tidak bisa menjawab pertanyaan jemaah akan dibawanya ke Pekanbaru. Pekanbaru adalah tempat UAS berdomisili. Jadi, UAS akan menjawab pertanyaan tersebut setelah dipelajarinya terlebih dahulu. Pada data 55 UAS mengungkapkan cara menjalin hubungan pertemanan dengan orang lain. UAS mencontohkan sebuah janji agar hubungan pertemanan tersebut tetap terjaga 
dengan cara tidak menceritakan keburukankeburukan temannya, dan lain-lain. Pada data 56 Uas sepertinya berikrar bahwa Indonesia itu adalah satu. Semua orang Indonesia adalah saudara dari mana pun asalnya dan apa pun sukunya.

\section{E. Tindak Tutur Deklarasi}

Tindak tutur deklarasi berfungsi untuk menyatakan sesuatu yang menunjukkan kekecewaan, tidak suka, dan rasa senang. Misalnya, memutuskan, membatalkan, melarang, mengizinkan, memberi maaf (Sherry HQ dan Agustina, 2012:64).

\section{a. Memutuskan}

Berikut adalah data tindak tutur ilokusi deklarasi 'memutuskan.'

57) "Maka semua yang ada di dalam masjid ini mendapatkan pahala."

58) "Maka dia sama seperti orang berjihad fisabilillah."

Data 57 merupakan deklarasi 'memutuskan' yang disampaikan UAS terkait sebuah kasus tentang keraguan masyarakat terhadap kehadirannya di sebuah masjid. Keraguan masyarakat tersebut terkait dengan masuk atau tidaknya jemaah ke dalam masjid ketika masjid tersebut penuh. UAS memutuskan bahwa semua mendapat pahala meskipun hanya di luar masjid. Data 58 adalah sebuah keputusan atau pendapat yang disampaikan UAS. Keputusan atau pendapat tersebut dilandasi dalil yang kuat. Keputusan tersebut terkait dengan seseorang yang keluar rumah dengan niat menuntut ilmu, maka dia sama dengan berjihad.

Dari sisi strategi bertutur yang digunakan UAS dalam berceramah, UAS memanfaatkan semua strategi bertutur. Strategi bertutur yang digunakan UAS tersebut adalah bertutur terus terang tanpa basa-basi, bertutur dengan basa-basi kesantunan positif, dan bertutur dengan basa-basi kesantunan negatif. UAS memang dikenal sebagai penceramah dengan cara penyampaiannya yang sangat mudah dipahami. Selain itu, UAS juga dikenal sangat kocak dan selalu melandasi kajiannya dengan dalil-dalil yang kuat.

\section{PENUTUP}

Berdasarkan hasil penelitian, ditemukan bahwa terdapat 58 kalimat tindak tutur ilokusi yang digunakan oleh UAS dalam berceramah. Secara rinci ke-58 tindak tutur ilokusi tersebut terbagi dalam 17 tindak tutur ilokusi reprentatif, 19 tindak tutur ilokusi direktif, 12 tindak tutur ekspresif, 8 tindak tutur komisif, dan 2 tindak tutur deklarasi. Secara umum, salah satu alasan UAS sangat disukai dan menjadi sangat terkenal saat ini adalah cara UAS bertutur dan menyampaikan ceramahnya. UAS sangat lugas dan meyakinkan serta cenderung tanpa basa-basi untuk hal-hal yang dianggap tidak bisa ditoleransi.

Peneliti menyarankan agar cara UAS bertutur dalam menyampaikan ceramahnya tetap dipertahankan. Bagi peneliti lain, diharapkan dapat menjadikan hasil penelitian ini sebagai rujukan untuk melakukan penelitian sejenis. Bagi khazanah ilmu pengetahuan, diharapkan penelitian ini dapat memberikan sumbangan positif untuk kemajuan ilmu pengetahuan khususnya di bidang kebahasaan terutama terkait dengan kajian tentang pragmatik.

\section{DAFTAR PUSTAKA}

Chaer, S.A. dan Agustina, L. 1995. Sosiolinguistik: Perkembangan Awal. Jakarta: PT Rineka Cipta.

Ellini, M., Juita, N., dan H. 2014. Tindak Tutur Ilokusi Ustaz Yusuf Mansur dalam Acara Wisarta Hati di Stasiun Televisi ANTV. Jurnal Bahasa Dan Sastra, Volume 2 (2), hlm. 1-14.

Elmita, W., Ermanto, Ratna, E. 2017. Tindak Tutur Direktif dalam Proses Belajar Mengajar di TK Nusa Indah Banuaran 
Padang. Jurnal Markah, Volume 1(2) hlm. 139-147.

Hibridani, I., I. 2010. Tindak Tutur Ilokusi dalam Wacana Kolom Pak Rivan di Koran Mingguan Diva. Semarang: Universitas Negeri Semarang. Skripsi

Kristanti, F. 2014. Tindak Tutur Direktif dalam Dialog Film "Ketika Cinta Bertasbih" Karya Chaerul Umam. Universitas Negeri Yogyakarta. Skripsi

Kusumaningsih, I. A. 2016. Tindak Tutur Ilokusi dalam Film Hors De Prix Karya Pierre Salvadori. Yogyakarta: Universitas Negeri Yogyakarta. Skripsi

Leech, G. 1993. Prinsip-prinsip Pragmatik. Jakarta: UI Press.

Nadar, F. X. 2009. Pragmatik dan Penelitian Pragmatik. Yogyakarta: Graha Ilmu.

Rahma, A. N. 2014. Analisis Tindak Tutur Ilokusi dalam Dialog Film Animasi Meraih Mimpi. Jurnal Skriptorium, 2 Nomor 2(Bahasa), 13-24.
Saleh, R. 2014. Gangguan Bahasa Alay di Facebook terhadap Komunikasi. Jurnal IPTEK-KOM. Volume 16(1), hlm. 4154.

Setyanto, B. 2015. Tindak Tutur Ilokusi Dialog Film $5 \mathrm{Cm}$ Karya Rizal Mantovani (sebuah Tinjauan Pragmatik). Surakarta: Universitas Muhammadiyah Surakarta. Skripsi

Sherry HQ, Agustina., dan N. J. 2012. Tindak Tutur Ilokusi dalam Buku Humor Membongkar Gurita Cikesa Karya Jaim Wong Gendeng dan Implikasinya dalam Pembelajaran Bahasa Indonesia. Jurnal Pendidikan Bahasa Dan Sastra Indonesia, Volume 1 (1), hal. 62-70.

Wijayanti, D. N. 2014. Tindak Tutur Tokoh dalam Novel Bekisar Merah Karya Amhad Tohari. Yogyakarta: Universitas Negeri Yogyakarta. 